DOI https://doi.org/10.30525/978-9934-588-91-4-29

\title{
INFORMATION POLICY IN CONDITIONS OF GLOBALIZATION
}

\author{
Antokhiv-Skolozdra O. M. \\ Candidate of Political Science, \\ Associate Professor at the Department of International Relations \\ and Diplomatic Service \\ Ivan Franko National University of Lviv \\ Lviv, Ukraine
}

In the context of total globalization through global informatization of almost all spheres of our society, the problems of transformation of such phenomena and concepts as «information», «information society», «globalization», «information policy of the state» acquire worldwide significance. Transformation of the state form of governance has led to a vision and understanding not only of the informational essence of the process itself, but also to state expansion, which allows us to consider the struggle for power both within the state and for spheres of influence outside the state in the format of information war.

«Its essence is to conquer countries and peoples by introducing their own protégés, bearers of their own ideology and their own interests into the leadership of a foreign country, exclusively by informational methods of influence, which are called democratic elections to power» [5, p. 243].

Our current time is characterized as transitional from «industrial society» to «information society», where concepts such as «information», «information society», globalization», «information policy of the state» are increasingly used, when the environment of civilization is radically transformed and, as a consequence, the following issues undergo transformations:

- methods of production and worldview of people;

- technologies of state administration;

- the place and role played by non-governmental organizations, transnational corporations and illegitimate criminal structures;

- opportunities, role and importance of mass media of modern civilization;

- bases and principles of formation of the system of information policy of the state. Today, the total growth of the importance of information in the life of mankind needs reconsidering in terms of its place and role not only on the household level, but also in politics and political science.

As V. Domaryov states: «The approach to the phenomenon of information itself ... is becoming primitive, and its deep essence and fundamental social function remain incomprehensible» [2, p. 317]. In the context of understanding the information policy of the state as a branch of social 
informatics, a significant problem is the issue of state regulation and the formation of pro-state worldview of society by introducing the relevant disciplines in educational courses. Analysis of the introduced specialties and successful areas of research in European universities show that considerable attention is dedicated to the so-called «information» specialties and sciences that use « a systemological» approach - that is systematic approach to the innovative stage of science development» [1, p. 32]. Since «the systemological approach to the national interests of the state is the main condition for the revival of the country and ensuring its security» [3, p. 156$]$.

Ukraine experiences definite lag in terms of training specialists in the field of information sciences. It occurs in the context of globalization in all spheres of civilization, which has a number of characteristics to be taken into account by the systemic governance of the state in both domestic and foreign policy [4, p. 96]. The most significant of them are:

- completion of the formation of a single information space of the state;

- imperfection of national and international information laws and, as a consequence, high information vulnerability of nations.

Functioning of transnational corporations simultaneously in different states and, as a consequence, in the format of incompatible legal norms, leads to the violation of the legal framework - the constitution and legislation of the nation-state.

The media play an enduring role in these processes, becoming a powerful tool of pressure on both society and the government. Accordingly, the perception of the media as the «fourth power» acquires a new meaning, when communication becomes a tool of impact on the person.

From the political point of view, it is essential, first of all, that by changing the way of perceiving the world, WMC turned public policy into a media process, making it the core of public policy, which led to the transformation of the place and role of communication in the political process.

However, in the format of the information space of civilization, the individual implements communication virtually, in direct contact only with the computer screen. As this process deepens, communication does not create a democratic society of free citizens who responsibly participate in political life, but a virtual space inhabited by atomized individuals.

In terms of the global nature of information policy and information security, developed democracies have begun to implement long-term government programs aimed at protecting national information structures: nowadays information weapons are being developed in more than 100 countries, while nuclear weapons are no more than in 20 states [6, p. 114].

However, political discussions on information policy and security issues have demonstrated differences in the approaches of different countries.

Meanwhile the position of developed democracies provides the following: 
- recognition of the problem of international information security as a hypothetical confrontation;

- transfer of consideration of the concept of international information security to the regional or thematic level;

- selection of such components as criminal and terrorist international information threats from the integral complex of the problem of international information security and creation of the international mechanism of control of similar information crimes, the position of states that do not belong to the countries of developed democracies, provides as follows;

- proposals for the establishment of international legal norms prohibiting the use of means of influencing the information resources of the state;

- creation of a special International Court of Information Crime;

- general development of technology for protection against information aggression [7, p. 228].

Thus, creation of the systemic information policy of the state with the view to revealing, modeling and foreseeing methods and technologies of state functioning in condition of globalization is the vital task nowadays.

\section{References:}

1. Бондаренко М. Ф. Підготовка професіоналів у галузі інформації для державної служби України. Харків: ООО «Компания СМИТ», 2004. $168 \mathrm{c}$.

2. Домарев В. В. Безопасность информационных технологий. Методология создания систем защиты. Київ: ДіаСофт, 2004. 688 с.

3. Прангишвили И. В. Системный подход, системное мышление и энтропизация фундаментальных знаний. М.: Наука, 2006. 224 с.

4. Расторгуев С. П. Информационная война. М: Радио и связь, 1999. $416 \mathrm{c}$.

5. Расторгуев С. П. Философия информационной войны. М.: Вузовская кн., 2001. 468 с.

6. Юзвишин И. И. Информациология. М.: Радио и связь, 1996. $220 \mathrm{c}$.

7. Rourke J. International Politics on the World Stage. London: McGrow Hill, 2005. 240 p. 